\title{
Spatial distribution pattern of Mytilus chilensis beds in the Reloncaví fjord: hypothesis on associated processes
}

\author{
Carlos Alberto Molinet Flores ${ }^{1 *}$, Manuel Alejandro Díaz Gomez, Camilo Bernardo Arriagada Muñoz \\ Leny Eunise Cares Pérez ${ }^{1}$, Sandra Lorena Marín Arribas ${ }^{2}$, Marcela Patricia Astorga Opazo² \\ and Edwin Juan Elías Niklitschek Huaquin ${ }^{3}$
}

\begin{abstract}
Background: Natural M. chilensis populations dominate habitats with a steep environmental gradient, and that are characterized by abrupt changes in salinity and exposure to desiccation. Although these populations are the source of seed supplies for the Chilean mussel culture industry (annual production around 250 thousand Tons), knowledge about natural populations is scarce. Based on video transect recordings, this study carries out research into one of the principal mussel beds and its associated epibenthic community in the Reloncaví Fjord, both along cross-shore and along-shore distribution gradients.

Results: Mytiluschilensis was observed between the middle intertidal zone and the upper subtidal zone (between approximately 9 and 26 psu), with a richer associated community towards the subtidal zone and the fjord mouth. The mussel Condition Index (total meat weight/shell length*100) in the intertidal zone was significantly greater than in the subtidal zone, which raises questions about the reproductive contribution of mussels along the intertidal mid-subtidal gradient.

Conclusions: Salinity and tidal variations, together with biological interactions, would seem to be key factors for explaining M. chilensis spatial distribution in the Reloncaví fjord, where beds appear to be in a contraction stage, as evidenced by M. chilensis scarcity towards the subtidal zone. The importance of these populations and their persistence in environments with high perturbation frequency, suggests a monitoring program should be implemented that considers both population spatial distribution and the changing environmental conditions.
\end{abstract}

Keywords: Salinity gradient; Mussel spatial distribution; Cross-shore contraction/expansion dynamic

\section{Background}

The mussel Mytilus chilensis is a bivalve that forms dense beds on hard and muddy substrates up to a depth of $10 \mathrm{~m}$, although, exceptionally, it has been observed at depths of up to $25 \mathrm{~m}$ (Lorenzen, et al. 1979; Zagal, et al. 2001). This species has separate sexes and a complex life cycle that alternates between a planktonic larval phase and a benthic adult phase (Buzeta, et al. 1988; Chaparro and Winter 1983). This gives rise to adult populations that are spatially structured in subpopulations according

\footnotetext{
* Correspondence: cmolinet@uach.cl

${ }^{1}$ Fisheries Research Program, Instituto de Acuicultura, Universidad Austral de Chile, Los Pinos s/n, Balneario Pelluco, casilla 1327, Puerto Montt, Chile Full list of author information is available at the end of the article
}

to habitat type and interconnected by means of larval dispersion (e.g., Hanski and Gilpin 1991; Roughgarden, et al. 1985).

Orensanz, et al. (1991), Orensanz and Jamieson (1998), and Orensanz, et al. (2006) proposed that analysis of the spatial dimension of population processes requires the identification of meaningful scales and adopted five scales for this purpose (Megascale, Macroscale, Mesoscale, Microscale, and Nanoscale). We will concentrate on the Mesoscale, corresponding to populations or subpopulations within a metapopulation, typically the scale of fishing grounds and beds (Orensanz et al. 1998). The dynamics of these subpopulations can be observed through their contraction and expansion, largely mediated by larval advection 
and habitat availability. These subpopulations may persist, become extinct, and re-emerge over periods of time that span more than a generation and changes can be slow and erratic (e.g., Caddy 1989; Hunt and Scheibling 2001).

Mytilus chilensis geographic distribution extends throughout the entire Chilean coastline and part of the Argentinean coast, dominating littoral communities in the fjords and channels of southern Chile that are characterized by marked salinity variations (Lorenzen, et al. 1979; Viviani 1979). These salinity variations give rise to a stratified system (Pickard 1971; Silva, et al. 1995; Valle-Levinson, et al. 2007), where it is assumed that vertical salinity gradients determine the spatial structure of the M. chilensis populations. This would occur mainly due to i) an effect on the planktonic phase, whereby the halocline functions as a chemical or physical barrier to those larvae attempting to migrate along these gradients (Gallager, et al. 2004; Lougee, et al. 2002; Young 1995) or ii) an effect on the survival of recruits and adults in a relatively variable environment.

Although Chilean mussel aquaculture activities harvest around 250,000 tons annually (Sernapesca 2013) and 99\% of juveniles are obtained by recruitment on artificial substrates located in areas surrounding natural banks, knowledge regarding basic ecological aspects of natural populations is scarce. The only information available relates to a few isolated aspects regarding estimated abundance in some areas (Leiva, et al. 2007; Lizama 2003) and some knowledge about larval stages present in the water column (Avendaño, et al. 2011; Barría, et al. 2012).

In coincidence with the growth in mussel culture activities, recruitment on the artificial substrates decreased in traditional collection areas (Avendaño et al. 2011). From the 1990s onwards, these were replaced by other recruitment areas, towards the fjords of the Los Lagos region (Leiva et al. 2007). However, from 2010 to date, M. chilensis recruitment on artificial substrates has decreased in the Reloncaví fjord, one of the main recruitment zones. As well as threatening the Chilean mussel culture industry, this situation raises basic issues that require clarification: i) Are the M. chilensis populations in the Reloncaví fjord contracting or expanding?; ii) What are the processes regulating $M$. chilensis population dynamics in fjord and estuarine systems?; iii) Can the decrease in M. chilensis recruitment in the Reloncaví fjord be explained by the decline in abundance of natural beds of this species?

The aim of this study is to describe the spatial distribution pattern of $M$. chilensis in the Reloncaví fjord, as well as its associated community and environmental variables. Using these results, we discuss some of the processes which may regulate the population dynamics of this species, their effects on recruitment in natural beds and seed collection, and the consequences for the mussel aquaculture industry.

\section{Methods}

This research work studies the spatial distribution of $M$. chilensis and its associated community along a shallow bathymetric gradient in the Reloncaví fjord. Given the spatial distribution of mussels previously observed in the study area, it was considered necessary to use the classification reported by Lizama (2003) (included as Additional file 1) to distinguish the two types of mussels observed along the cross-shore distribution: $M$. chilensis covered by the barnacle Elminius kingii (hereafter referred to as 'covered') in the middle intertidal zone, and the mussels with little or no epibiont presence (hereafter referred to as 'clean') in the subtidal zone.

The M. chilensis condition index (total meat weight/ shell length $\times 100)$ was characterized monthly from September 2013 to May 2014. Additionally, we studied food supply, expressed as phytoplanktonic biomass, as well as temperature and salinity in the water column.

\section{Study area}

The study area focused on the Reloncaví fjord that has a depth of just over $450 \mathrm{~m}$ and three moraine banks: at the head, in the middle, and at the mouth of the fjord. The tidal ranges in the fjord are 6 to $7 \mathrm{~m}$ during spring tides and 5 to $6 \mathrm{~m}$ during neap tides (Valle-Levinson et al. 2007), with greater tidal heights towards the mouth $(50 \mathrm{~cm})$ than at the head. Considering these features, Daneri, et al. (2009) proposed the division of the fjord into four zones (Boca, Marimelli, Puelo, and Cochamó) and we use this division to study the mussel's beds in the fjord. The selection of specific sampling stations was based on previous work by Lizama (2003) in order to have a reference with which to compare results, considering the limited literature available on mussel beds in Chile. Specifically, 13 of the 22 sites sampled by Lizama (2003) along the fjord (Figure 1) were studied along cross-shore gradients, in vertical profiles of approximately $15 \mathrm{~m}$ between the high tide line $(0 \mathrm{~m})$ and the subtidal zone.

The $M$. chilensis condition index and environmental variables were obtained monthly in three sites representing the Boca, Marimelli, and Puelo zones. Cochamó was excluded from monthly surveys due to the elevated costs of this sampling activity.

\section{Characterization of $M$. chilensis populations and associated community}

The epibenthic species (>10-mm size) in the 13 sampling stations were characterized by recording five video transects, 20- to 26-m length (separated by 50 to $140 \mathrm{~m}$ ), perpendicular to the coast line (cross-shore). In order to record the video transect, a Seaviewer camera (mounted on a sled) was towed from a depth of 12 to $15 \mathrm{~m}$, to the surface. The sled was maintained more or 


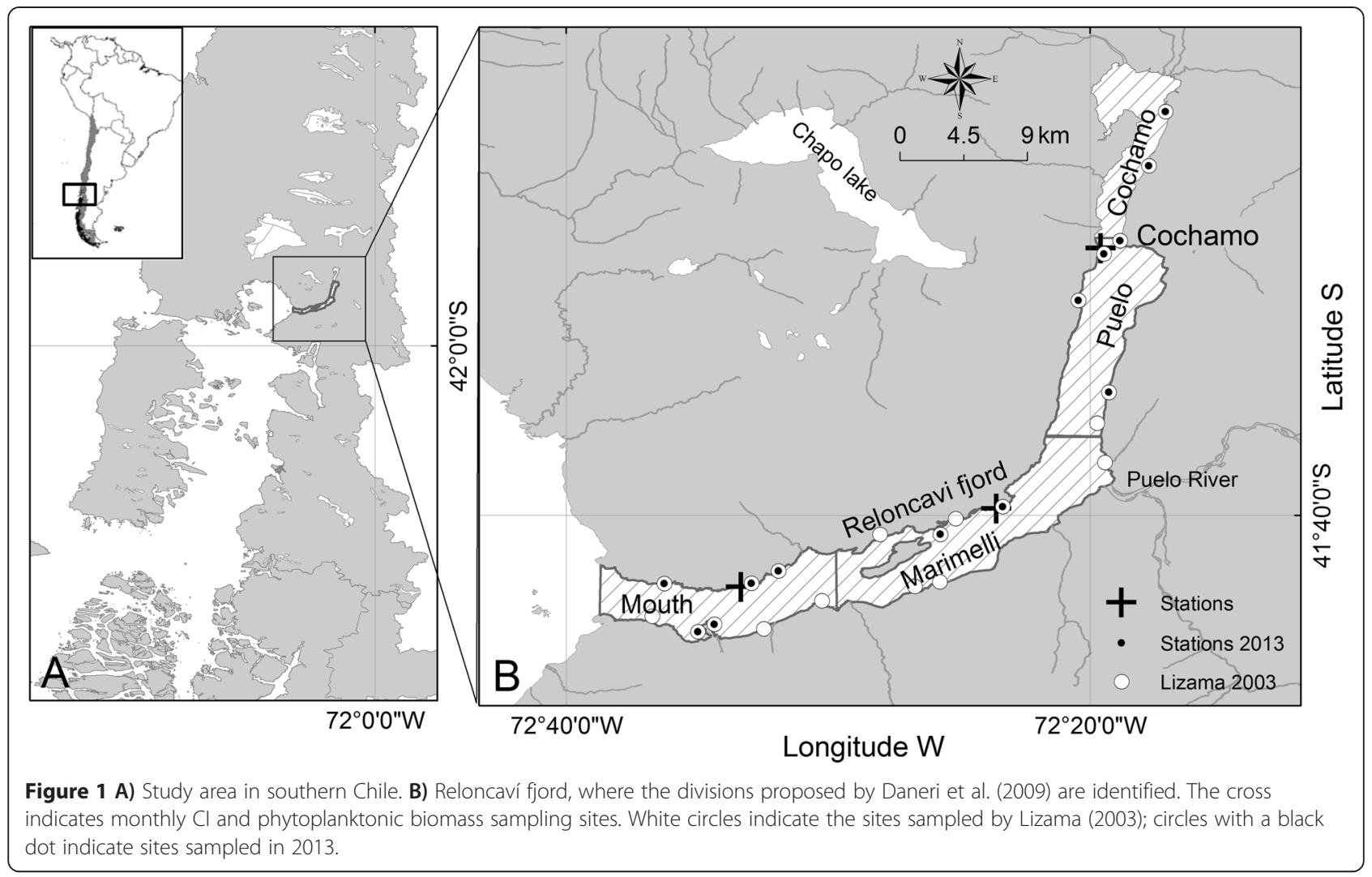

less perpendicular at $35 \mathrm{~cm}$ from the bed and accompanied by a shellfish diver, who, in turn, indicated the onset of $M$. chilensis presence, which coincided with the end of the Aulacomya atra (ribbed mussel) presence. The camera was equipped with two lasers parallel to its line of vision, separated by a 10 -cm-wide interval; this enabled estimation of width of the visual field and, finally, made it possible to obtain a qualitative classification of the organism size.

The position of the sled was monitored at 1-s intervals, using a Micron Nav USLB tracking system, mounted on the sled, enabling confirmation of transect demarcation and verification of the bathymetric profile associated with each video transect. In each transect, mussel samples were collected from the intertidal and subtidal level; to this end, a $25 \times 25 \mathrm{~cm}$ quadrant was set up, and all mussels present within the quadrant were removed. All the mussels collected were counted and their valve length measured using a vernier caliper (1$\mathrm{mm}$ accuracy).

\section{Condition index and environmental variables}

Thirty covered mussels (from the middle intertidal zone) and 30 clean mussels (from the subtidal zone) of between 50- and 70-mm length were collected at monthly intervals in three sites of the fjord (representing the Boca, Marimelli, and Puelo zones, Figure 1). Total length and drained wet weight of meat were obtained from these specimens. Length of each specimen was recorded using a vernier caliper accurate to $\pm 1 \mathrm{~mm}$. The meat weight of each specimen was obtained by weighing on an electronic precision scale \pm 0.01 gr.

Mussel condition index (CI) was estimated as $\mathrm{CI}=$ $\frac{\mathrm{PT}}{\mathrm{LT}} \times 100$, where TW is total meat weight in grams and $\mathrm{TL}$ is total shell length in millimeters (Anderson and Neumann 1996).

Simultaneously, integrated water samples were collected in two strata, 0 - to 5-m and 15- to 10-m depth, using a hose, $20-\mathrm{m}$ length and $2.5-\mathrm{cm}$ diameter, to determine chlorophyll in the water column. Two hundred milliliters of water was filtered at a pressure below 100 psi, using fiberglass filters (GF-75 MFS, 25-mm diameter). Estimation of autotrophic biomass measured as chlorophyll-a ( $\mu \mathrm{g} \mathrm{L-1}$ ) was undertaken using the fluorometric method (Turner fluorometer). Temperature and salinity profiles were registered with a Seabird19 plus profiler. These were processed using the software provided by the manufacturer.

\section{Video-transect processing}

The images were projected onto the computer screen on a grid of 100 separate points, where the taxonomic groups were identified to the most specific level possible, 
depending on the image quality, according to Häuseermann and Försterra (2009). The sample comprises a frame identified by recording time (hh:mm:ss), where the image is frozen in order to identify and count all the taxonomic groups observed, estimate algal coverage, and identify substrate type. Each of the frames sampled was georeferenced using Micron Nav USBL tracking system information (obtaining the $\mathrm{x}, \mathrm{y}$, and $\mathrm{z}$ coordinates referring to the position of vessel). This enabled elaboration of distribution profiles for the main species observed, with a $1-\mathrm{m}$ resolution.

\section{Statistical analysis}

M. chilensis spatial distribution was evaluated by applying geostatistical methods, following Roa-Ureta and Nicklitschek (2007), to adjust two independent models: a binomial model for the presence/absence data and a Gauss model for the positive density observations (boxcox transformed). Thus, two separate spatial correlation processes were evaluated. The first model evaluated whether there was spatial correlation in mussel distribution (presence/absence) in the area. The second model evaluated whether the positive observations were spatially correlated by means of the subset frames/video, where $M$. chilensis was present. The statistical significance of the spatial correlation was evaluated, based on a comparison of likelihood of the spatial model against an equivalent non-spatial model (pure nugget). Selection of the best model was undertaken using the Akaike information criterion (AIC) (Akaike 1974), where the preferred model presented the minimum AIC value, considering a $\geq 2$ unit difference (Burnham and Anderson 2004).

The size distribution of sampled mussels was assessed relative to zone and strata (intertidal and subtidal) using regression models for ordinal data (McCullagh 1980) and the ordinal package in R 3.0.2 (Christensen 2012).

\begin{tabular}{l}
$\begin{array}{l}\text { Table } 1 \text { Hypothesis used for the comparative analysis of } \\
\text { M. chilensis size distribution in four bathymetric zones } \\
\text { and two strata }\end{array}$ \\
\begin{tabular}{ll}
\hline Model & Hypotheses \\
\hline Common & $\begin{array}{l}\text { There is a common pattern of mussel size } \\
\text { distribution along the entire fjord }\end{array}$ \\
Two depth strata & $\begin{array}{l}\text { There are two patterns of mussel size } \\
\text { distribution: subtidal and intertidal }\end{array}$ \\
Boca vs other sectors & $\begin{array}{l}\text { Boca shows a different pattern of mussel size } \\
\text { distribution compared to the other three sectors }\end{array}$ \\
Two zones & $\begin{array}{l}\text { There are two patterns of size distribution: } \\
\text { Boca-Marimelli and Puelo-Cochamó }\end{array}$ \\
Four zones & $\begin{array}{l}\text { There is a different mussel size distribution } \\
\text { pattern for each zone } \\
\text { There is a different mussel size distribution } \\
\text { pull differences }\end{array}$
\end{tabular} \\
\hline
\end{tabular}

To this end, mussel length distribution was separated into six intervals of $15 \mathrm{~mm}$ each. We evaluated six possible hypotheses as shown in Table 1.

Monthly CI and chlorophyll-a variation was evaluated through the application of a linear model that considered the predictor variables: zone, stratum (as a fixed effect), and month (as a random variable), using the nlme package (Pinheiro et al. 2013). The residuals of both models were previously transformed with a box-cox function using the car package (Fox and Sanford 2010) in $R$ 3.0.2 (The $R$ Development Core Team 2013). Additionally, CI was evaluated through the application of a linear model that considered the predictor variables: temperature, salinity, and chlorophyll-a.

Variation in number of species and abundance per species for each sample zone was evaluated by means of non-metric multidimensional scaling; a Bray-Curtis similarity matrix was constructed, and Analysis of Similarities (ANOSIM) with 999 permutations was undertaken. A Similarity Percentage (SIMPER) analysis of species representatively among zones was also carried out, using PRIMER-E 5.0. ANOSIM generates an $R$ statistic that varies between 0 and 1 . The value $R=1$ represents the absolute value of similarity, while $R=0$ represents absolute dissimilarity among groups. The $R$ value observed is contrasted with the $R$ value obtained from the 999 permutations undertaken. If the similarity percentage within each group is less than that between groups $R \cong 0$, then groups will be significantly similar $(P \geq 0.05)$. The species responsible for the differences observed between zones were identified by means of Similarity Percentage (SIMPER) analysis.

\section{Results}

\section{Characterization of $M$. chilensis beds and associated} community

We identified 42 epibenthic taxonomic groups in the 13 sampling stations, with a predominance of the mussels M. chilensis and Aulacomya atra, the crustacean Elminius kingii, and species of Echinodermata (Tables 2 and 3 , Additional file 2). Highest taxon richness was observed in the mouth of the fjord (21 to 28 species), while lowest taxon richness and abundance of individuals was observed at the head of the fjord in Cochamó (five to nine species) (Figure 2). Among the four zones studied, significant differences in taxa similarity were only observed between the Boca zone and the other zones (Table 2). Mainly, Gastropoda, Echinodermata, Mitilidae, and Crustacea were observed in the Boca zone of the fjord whereas, towards the head of the fjord (Cochamó), E. kingii and the mussels $A$. atra and M. chilensis dominated (Table 3).

Mytilus chilensis distribution was observed between the middle intertidal and upper subtidal zone in 12 of 
Table 2 Result of a non-metric multidimensional scaling that compares the four sampling zones

\begin{tabular}{|c|c|c|c|}
\hline Zones & Puelo & Marimelli & Boca \\
\hline Cochamó & 0.222 & 0.417 & 0.887 \\
\hline Puelo & & 0.167 & 0.610 \\
\hline Marimelli & & & 0.655 \\
\hline
\end{tabular}

the 13 stations sampled (between approximately 2 and $12 \mathrm{~m}$ in our vertical profile (Figure 3)). Covered M. chilensis were observed in the intertidal zone (maximum density $=1,100 \mathrm{Ind} / \mathrm{m}^{2}$ ); while in the subtidal zone, the mussels were mainly clean (maximum density $=350$ $\mathrm{Ind} / \mathrm{m}^{2}$ ). Mussel distribution increased in depth towards the head of the fjord (Figure 3), in coincidence with the accentuation of a salinity gradient between 8 and 26 psu. Ribbed mussel was observed between 6 and $13 \mathrm{~m}$ of the vertical profile (subtidal), with the exception of the Cochamó zone. Highest ribbed mussel density (maximum density $=900 \mathrm{Ind} / \mathrm{m}^{2}$ ) was observed in the Marimelli and Puelo zones (Figure 3). Echinodermata, represented mainly by Asteroidea, Loxechinus albus, and Arbacia dufresnei, were observed principally in the Boca zone, between approximately 8 and $14 \mathrm{~m}$ (Figure 3).

Throughout the sampling, salinity between 0 and $15 \mathrm{~m}$ presented a gradient ranging from 5 to $30 \mathrm{psu}$, which, at the mouth of the fjord, included an area from the surface to over 10-m depth; whereas, at the

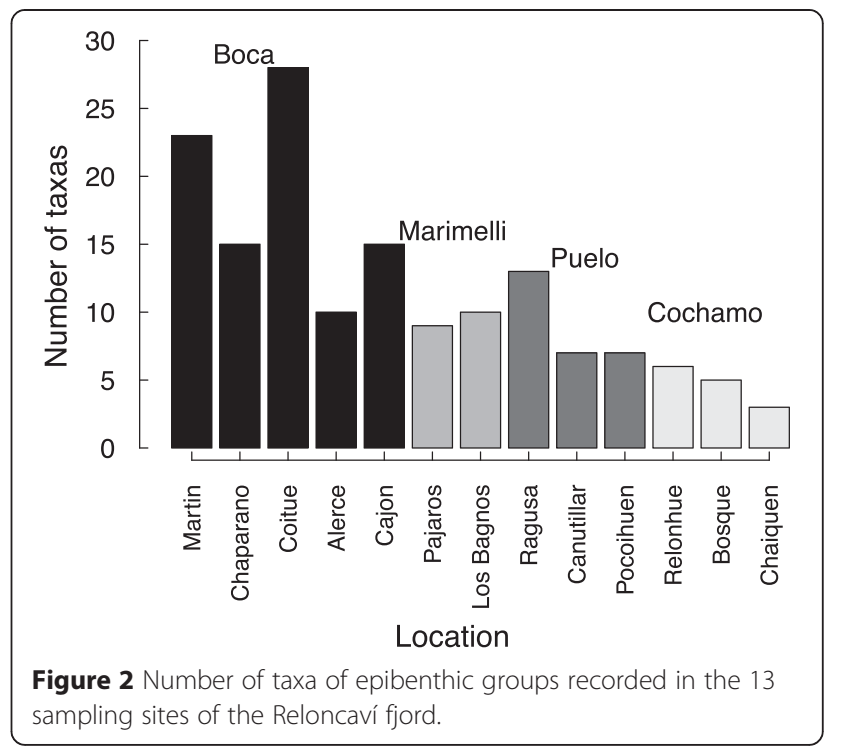

head of the fjord, it ranged from the surface to over $15-\mathrm{m}$ depth. The most pronounced salinity gradient was observed between approximately 8 and 26 psu, shaded in grey in Figure 3.

Geostatistical analysis revealed evidence of spatial correlation in the distribution of mussels (presence/absence) in $83 \%$ of cases (AIC spatial model to AIC nonspatial model $>2$ ), with a range of spatial proximity that varied between 2 and $24 \mathrm{~m}$ and an average range of $6.8 \mathrm{~m}$. Evidence of spatial correlation in M. chilensis density was only observed in two sites, with a range of

Table 3 Results of non-metric multidimensional scaling for taxa diversity in four zones of the Reloncaví fjord

\begin{tabular}{|c|c|c|c|c|c|c|c|}
\hline Zone & $\begin{array}{l}\text { Average } \\
\text { similarity }\end{array}$ & Taxa & $\begin{array}{c}\text { Average } \\
\text { abundance }\end{array}$ & $\begin{array}{l}\text { Average } \\
\text { similarity }\end{array}$ & $\begin{array}{c}\text { Standard deviation } \\
\text { similarity }\end{array}$ & $\begin{array}{c}\text { Contribution } \\
(\%)\end{array}$ & $\begin{array}{c}\text { Accumulated } \\
\text { contribution (\%) }\end{array}$ \\
\hline \multirow[t]{2}{*}{ Cochamó } & 40.5 & E. kingii & 58.3 & 35.3 & 1.7 & 87.2 & 87.2 \\
\hline & & M. chilensis & 45.0 & 3.0 & 0.6 & 7.5 & 94.7 \\
\hline \multirow[t]{3}{*}{ Puelo } & 48.2 & M. chilensis & 75.7 & 23.8 & 4.0 & 49.3 & 49.3 \\
\hline & & A. atra & 56.3 & 15.4 & 10.0 & 31.9 & 81.2 \\
\hline & & E. kingii & 45.3 & 4.6 & 0.6 & 9.6 & 90.8 \\
\hline \multirow[t]{5}{*}{ Marimelli } & 77.8 & E. kingii & 144.5 & 24.3 & & 31.3 & 31.3 \\
\hline & & A. atra & 82.0 & 18.1 & & 23.3 & 54.6 \\
\hline & & Crepidulasp & 57.5 & 12.9 & & 16.5 & 71.1 \\
\hline & & Macroalgas & 75.5 & 10.1 & & 13.0 & 84.1 \\
\hline & & M. chilensis & 43.5 & 6.4 & & 8.3 & 92.3 \\
\hline \multirow[t]{7}{*}{ Boca } & 58.7 & Crepidulasp & 93.6 & 18.1 & 2.2 & 30.8 & 30.8 \\
\hline & & M. chilensis & 46.6 & 11.0 & 5.8 & 18.8 & 49.6 \\
\hline & & A. atra & 42.2 & 8.3 & 2.1 & 14.1 & 63.7 \\
\hline & & L. albus & 29 & 5.4 & 1.6 & 9.1 & 72.8 \\
\hline & & E. kingii & 26.8 & 4.7 & 1.1 & 8 & 80.8 \\
\hline & & A. dufresnei & 29.8 & 3.1 & 0.7 & 5.2 & 86.1 \\
\hline & & A. chilensis & 16 & 2.5 & 1.0 & 4.3 & 90.4 \\
\hline
\end{tabular}




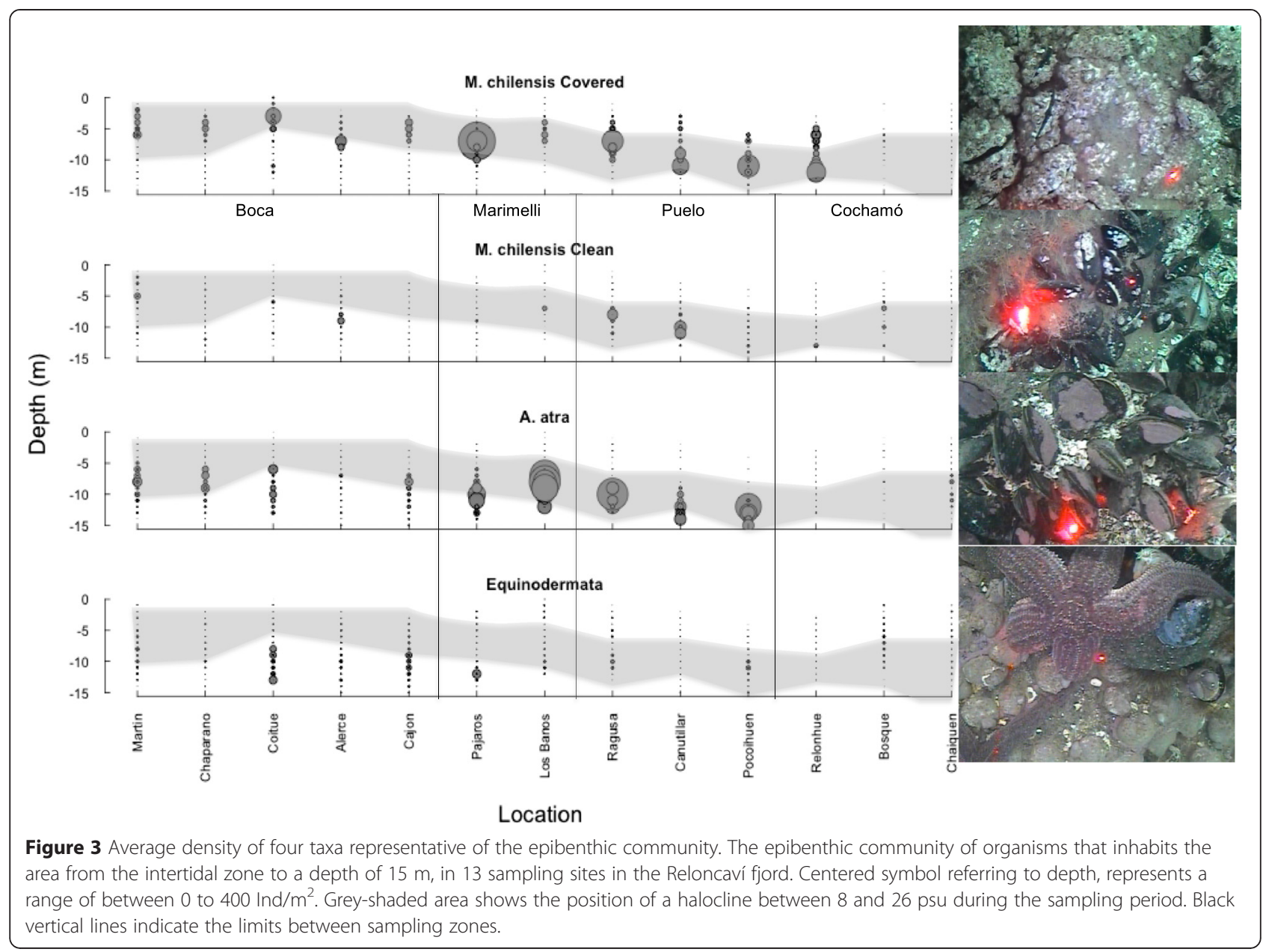

4 and $8 \mathrm{~m}$ (Table 4). These results suggest that we observed the effect of spatial proximity in mussels, but we did not observe spatial dependence on mussel density. Our results could be affected by the sampling design used and the narrow belt of mussels (transects perpendicular to the coastline), since other authors found that the distribution of adult mussels showed spatial dependence along transects of $10 \mathrm{~m}$ (see Erlandsson and McQuaid 2004).

Size distribution of covered M. chilensis was symmetric towards the mouth of the fjord, while towards the head, size distribution showed a bias towards larger individuals (Figure 4). Clean mussels were only found in the Boca and Puelo zones (Figure 4), presenting a biased size distribution towards mussels measuring 40 - to $80-\mathrm{mm}$ length. The ordinal model applied showed that the full model (difference between stratum and zones) was the most informative of the six models assessed (AIC $=12,052$ ), with regard to explaining the size distribution of mussels along the Reloncaví fjord (Table 5).

\section{Condition index and environmental variables}

The $M$. chilensis condition index was significantly greater towards the mouth of the fjord $\left(\mathrm{F}_{2,1525}=158.91\right.$; $P=0.0001$ ), with values over $90 \%$ and reaching up to $230 \%$, during the study period, while at the Puelo site, CI remained at around 90\% (Table 6, see also Figure S1 in Additional file 2). In turn, significant differences in CI were observed between strata $\left(F_{2}, 1525=158.91 ; P=\right.$ 0.0001), with greater CI between 0- and 5-m depth (Table 6, see also Figure S2 in Additional file 2). The condition index showed no significant variations due to the changes in chlorophyll-a concentration, salinity, or temperature during the study period.

Phytoplanktonic biomass varied between 0.5 and $9 \mu \mathrm{g}$ chlorophyll-a $\mathrm{L}^{-1}$ throughout the entire study period, with higher values in September 2014. Significant differences were only observed in the phytoplanktonic biomass between the Marimelli and Puelo zones, with greater phytoplanktonic biomass in the latter site $\left(\mathrm{F}_{2,133}=4.07 ; P=0.0192\right)$ (Table 7 , see also Figure $\mathrm{S} 2$ in Additional file 2). No significant differences were 
Table 4 Results of geostatistic analysis following Roa-Ureta and Niklitschek (2007)

\begin{tabular}{|c|c|c|c|c|c|c|c|c|c|}
\hline Zone & Sector & $\begin{array}{l}\text { Area with } \\
\text { M. chilensis }\end{array}$ & $\begin{array}{l}\text { Number of } \\
\text { M. chilensis } \\
\text { sample }\end{array}$ & $\begin{array}{l}\text { AIC } \\
\text { spatial } \\
\text { model }\end{array}$ & $\begin{array}{l}\text { AIC non- } \\
\text { spatial } \\
\text { model }\end{array}$ & $\begin{array}{l}\text { Average range spatial } \\
\text { correlation }(\mathrm{m})\end{array}$ & $\begin{array}{l}\text { AIC spatial } \\
\text { dependence }\end{array}$ & $\begin{array}{c}\text { AIC non- } \\
\text { spatial } \\
\text { dependence }\end{array}$ & $\begin{array}{c}\text { Average } \\
\text { range spatial } \\
\text { dependence }(m)\end{array}$ \\
\hline 4 & Chaiquen & $0 \%$ & 0 & & & & & & \\
\hline 4 & El Bosque & $13 \%$ & 100 & -0.4 & -1.3 & 0.8 & 58.6 & 54.6 & \\
\hline 4 & Relonhue & $74 \%$ & 1,067 & 5.2 & 12.5 & 1.9 & 327.0 & 318.0 & \\
\hline 3 & Pocoihuen & $36 \%$ & 509 & -299.0 & -74.0 & 3.2 & 184.6 & 185.3 & \\
\hline 3 & Canutillar & $39 \%$ & 728 & -572.0 & -489.0 & 24.2 & 243.3 & 246.5 & 4 \\
\hline 3 & $\begin{array}{l}\text { Costa } \\
\text { Ragusa }\end{array}$ & $51 \%$ & 1,240 & 1.4 & 9.4 & 6.1 & 299.0 & 319.0 & 8 \\
\hline 2 & Los Baños & $15 \%$ & 206 & -692.5 & -542.9 & 6.5 & 70.3 & 67.1 & \\
\hline 2 & $\begin{array}{l}\text { Punta } \\
\text { Pajaros }\end{array}$ & $24 \%$ & 794 & 0.3 & 28.9 & 2.3 & 165.8 & 165.1 & \\
\hline 1 & Cajon & $23 \%$ & 291 & 1.1 & 67.9 & 7.1 & 106.1 & 102.1 & \\
\hline 1 & $\begin{array}{l}\text { Punta } \\
\text { Alerce }\end{array}$ & $29 \%$ & 384 & -327.0 & -239.8 & 11.4 & 150.4 & 146.4 & \\
\hline 1 & Coitue & $32 \%$ & 455 & 1.2 & 23.4 & 2.6 & 175.7 & 171.7 & \\
\hline 1 & Chaparano & $16 \%$ & 202 & 6.7 & 8.3 & 1.2 & 75.8 & 71.8 & \\
\hline 1 & $\begin{array}{l}\text { Bahía } \\
\text { Martín }\end{array}$ & $36 \%$ & 575 & 5.6 & 13.1 & 2.0 & 202.0 & 198.0 & \\
\hline
\end{tabular}

To evaluate the existence of spatial correlation in $M$. chilensis distribution (presence/absence) and spatial dependence in $M$. chilensis density in each of the sites studied. Sites with M. chilensis spatial pattern, determined by lower AIC, are indicated in italics.

observed between the two strata studied $\left(\mathrm{F}_{2,133}=2.72\right.$; $P=0.1013$ ) (Table 7).

The water column remained stratified during the sampling periods, with a shallower halocline towards the mouth of the fjord and during the summer months. Salinity varied between approximately 8 psu on the surface and $32 \mathrm{psu}$ at $15-\mathrm{m}$ depth. Thermocline was greatest between November and January, with maximum values of $20^{\circ} \mathrm{C}$ on the surface and $11^{\circ} \mathrm{C}$ to $12^{\circ} \mathrm{C}$ at $15-\mathrm{m}$ depth (Figure 5).

\section{Discussion}

As reported by Viviani (1979), M. chilensis was observed in narrow 'belts' of approximately $6 \mathrm{~m}$ wide in the Reloncaví fjord, in a habitat characterized by the presence of a steep salinity gradient between approximately 9 and 26 psu (see also Daneri et al. 2009). In turn, the taxa composition presented a gradient from the mouth towards the head of the fjord, associated with the deepening of the halocline. This suggests that salinity gradient plays an important role in structuring the community associated with $M$. chilensis, where this species is confined to a narrow habitat that is bordered by physical-chemical restrictions towards the upper boundary (Aquaterra Ingenieros Ltda. 2010; Buschbaum, et al. 2009). Towards the inferior zone of its distribution, $M$. chilensis seems to compete for substrate with $A$. atra, which has only been observed on culture ropes where the two species recruit together
(Marambio, et al. 2012). Both the urchins A. dufresnii and starfish observed in our study are carnivorous and therefore may be predators of $A$. atra and M. chilensis (Brogger, et al. 2010; Häuseermann and Försterra 2009; Zaixso 2004). However, it is likely that the salinity gradient in the water column restricts the periods in which these predators have access to these prey in stratified environments.

The structure of the intertidal and shallow subtidal communities in rocky systems has been described and discussed in scientific literature (Connell 1961; Hunt and Scheibling 2001; Paine 1974; Reusch and Chapman 1997). These authors proposed the presence of intraand interspecific competition between organisms that adhere to the substrate, as well as predation, for example, by Echinodermata. The limited information available on intertidal ecology in Chilean fjords and channels restricts the understanding of patterns observed. Considering the demand for use of these coastal areas (e.g., for aquaculture, fisheries, tourism, etc., see Molinet, et al. 2014), research into coastal ecology must be undertaken in order to provide the necessary knowledge to ensure that the correct decisions are taken in the context of sustainable development.

The size distribution of $M$. chilensis showed significant differences between the intertidal and subtidal zones and among the four areas studied, suggesting a local pattern of size distribution with a low number of recruits at the head of the fjord. Erlandsson and McQuaid (2004) 


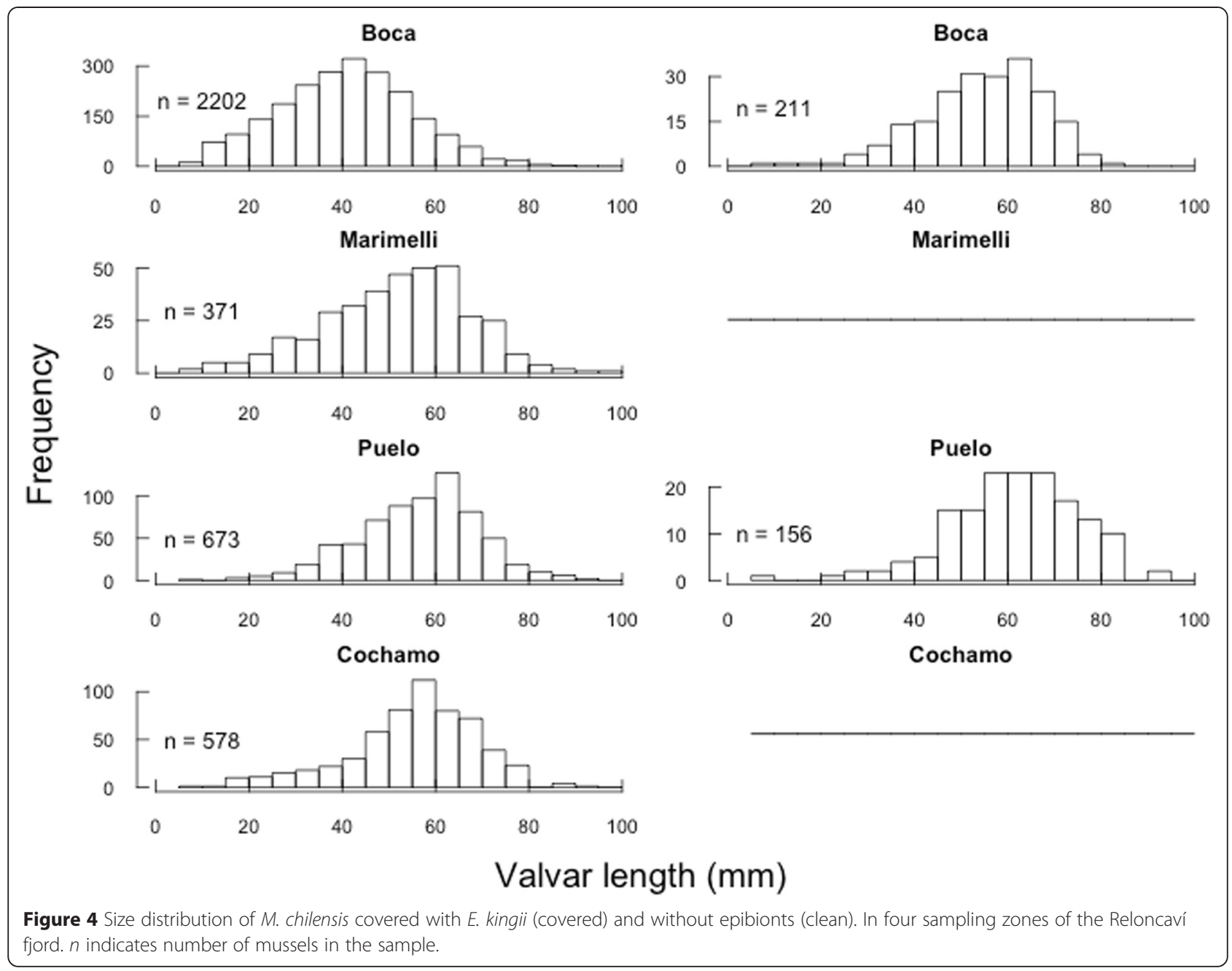

observed that the distribution of larger recruits of Perna perna showed spatial dependence at 10-m transects, revealing a spatial structure related to that of adults. Furthermore, the size distribution pattern of area-specific mussels are influenced by their mortality and growth rates due to local conditions, as observed by McQuaid and Lindsay (2000) for the mussel P. perna in exposed and sheltered environments. Thus, studying variations in mortality and growth rates associated with the salinity gradient affecting the mussel bed and how they are expressed in the size distribution pattern observed will contribute to understanding the population dynamics of M. chilensis in stratified systems, such as the Reloncaví fjord.

The steep saline gradient observed between 3 and $10 \mathrm{~m}$ of the water column appears to modulate the

Table 5 Evaluation of the size distribution of mussels from zones and depth stratum (intertidal and subtidal)

\begin{tabular}{|c|c|c|c|c|c|}
\hline Models & Number of parameters & AIC & Log likelihood & LR statistic & $P\left(x^{2}\right)$ \\
\hline Common & 5 & 13,100 & -6544.9 & & \\
\hline Two depth stratum & 6 & 12,977 & -6482.6 & 124.587 & $2.20 \mathrm{E}-16$ \\
\hline Boca vs other sectors & 6 & 12,254 & -6121.0 & 723.168 & $2.20 \mathrm{E}-16$ \\
\hline Two zones & 7 & 12,229 & -6107.4 & 27.269 & 1.77E-07 \\
\hline Four zones & 8 & 12,219 & -6101.7 & 11.397 & 0.0007356 \\
\hline Full differences & 10 & 12,052 & -6015.8 & 171.677 & $2.20 \mathrm{E}-16$ \\
\hline
\end{tabular}

Using regression models for ordinal data (McCulagh, 1980).

Best model fit was determined by the lowest Akaike's information criterion (AIC), and its statistical significance was assessed by a likelihood-ratio test (LR) with $x^{2}$ distribution. 
Table 6 Statistical significance of variation in $M$. chilensis condition index

\begin{tabular}{|c|c|c|c|c|}
\hline Effect & DF numerator & DF denominator & $F$ value & $\operatorname{Pr}(>|F|)$ \\
\hline (Intercept) & 1 & 1,575 & 17505.64 & $<.0001$ \\
\hline Stratum & 1 & 1,575 & 158.91 & $<.0001$ \\
\hline Zone & 2 & 1,575 & 317.15 & $<.0001$ \\
\hline \multicolumn{5}{|l|}{ a posteriori Tukey test } \\
\hline Hypothesis & Estimated & Standard error & $z$ value & $\operatorname{Pr}(>|z|)$ \\
\hline Boca $=$ Marimelli & -0.42 & 0.030 & -13.98 & $<.0001$ \\
\hline Boca $=$ Puelo & -0.76 & 0.030 & -25.16 & $<.0001$ \\
\hline Marimelli $=$ Puelo & -0.34 & 0.030 & -11.40 & $<.0001$ \\
\hline Covered $=$ clean & -0.29 & 0.025 & -11.94 & $<.0002$ \\
\hline
\end{tabular}

In four sampling zones and two strata (intertidal and subtidal), where covered and clean mussels were collected, where sample date is the random variable. Variance analysis and an a posteriori Tukey test are presented. DF is degrees of freedom.

marked changes in $M$. chilensis abundance, as well as characteristics such as valve cover ranging from mussels completely covered by E. kingii in the intertidal zone to totally clean mussels in the subtidal zone. Along this gradient, those individuals in the intertidal zone (covered) present a better CI than the clean individuals, throughout this study. Additionally, mussel CI decreases significantly towards the head of the fjord, which may be associated, principally, with effects of the deepening halocline, food availability, and environmental stress. The latter has been reported to affect the gonadic index in the case of Mytilus californianus and, therefore, their contribution to reproduction (Petes et al. 2008).

Observations undertaken in our study raise new questions with regard to the spatial distribution pattern of $M$. chilensis and the differences in its condition index on a scale of meters. Our hypothesis is that the environmental gradient observed in this narrow belt configures a 'source-sink' habitat scenario (sensu Pulliam 1988) for M. chilensis that requires further in-depth study. The existence of a source-sink habitat for M. chilensis in the spatial scale observed would imply that, along this narrow and highly perturbed gradient, part of the population does not contribute (or contributes little) to population growth.

On the other hand, the scarcity of clean mussels and lower densities of covered mussels observed in our study, compared to the observations of Lizama (2003) (see Figure S3 Additional file 1), suggest a narrowing of the space occupied by the mussel belt and a decrease in the abundance of M. chilensis in the Reloncaví fjord. Unfortunately, we found no previous information regarding mussel belt width or the role that covered mussels (in the intertidal) and clean mussels (in the subtidal) may have; thus, it is suggested that these aspects be included in future studies.

One approach to studying changes in the abundance of mussel belts could be the contraction/expansion dynamics of subpopulations (e.g., Orensanz et al. 1998; Orensanz et al. 2006). Hunt and Scheibling (2001) described aspects of the expansion and contraction of mussel beds, indicating that they can recover over a relatively short period of time. In particular, we suggest studying changes in the cross-shore spatial distribution and abundance of mussels and their relationship with changes in water column salinity, rain, and rain runoff.

Table 7 Statistical significance of variation in phytoplanktonic biomass

\begin{tabular}{|c|c|c|c|c|}
\hline Effect & DL numerator & DL denominator & $F$ value & $\operatorname{Pr}(>|F|)$ \\
\hline (Intercept) & 1 & 133 & 0.71 & 0.3994 \\
\hline Stratum & 1 & 133 & 2.72 & 0.1013 \\
\hline Sector & 2 & 133 & 4.07 & 0.0192 \\
\hline \multicolumn{5}{|l|}{ a posteriori Tukey test } \\
\hline Linear hypothesis & Estimated & Standard error & $z$ value & $\operatorname{Pr}(>|z|)$ \\
\hline Boca $=$ Marimelli & -0.335 & 0.14587 & -2.294 & 0.0772 \\
\hline Boca $=$ Puelo & 0.047 & 0.14587 & 0.325 & 0.9856 \\
\hline Marimelli $=$ Puelo & 0.382 & 0.14587 & 2.619 & 0.0325 \\
\hline 0 to $5 \mathrm{~m}=5$ to $15 \mathrm{~m}$ & -0.196 & 0.11911 & -1.650 & 0.3016 \\
\hline
\end{tabular}

In three sampling zones and two strata $(0$ to $5 \mathrm{~m}$ and 5 to $15 \mathrm{~m}$ ), with sample date as a random variable. Variance analysis and an $a$ posteriori Tukey test are presented. DL is degrees of liberty. 


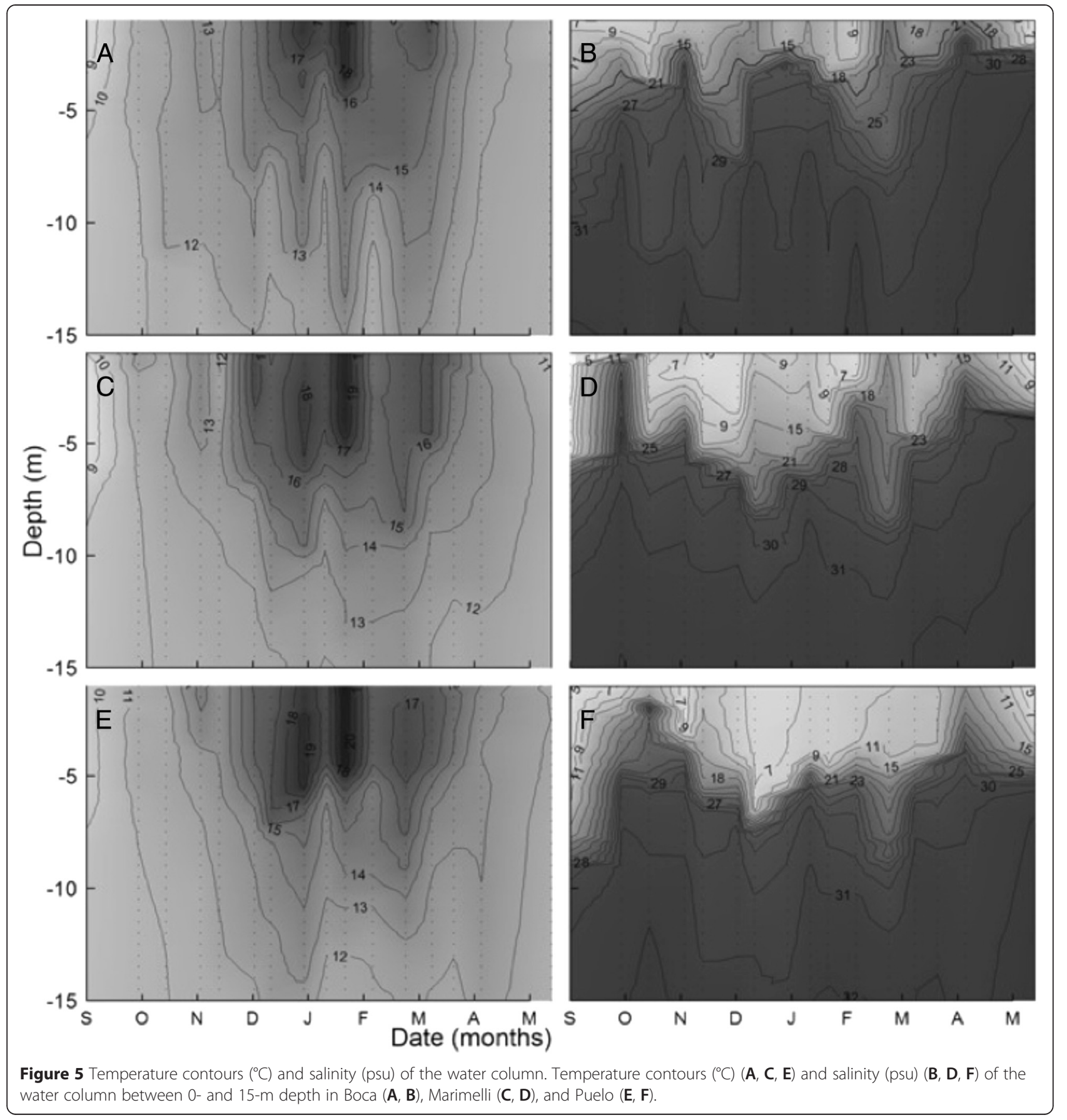

Thus, the cross-shore contraction-expansion dynamics of mussel beds appear to be an effective instrument for monitoring these spatially structured populations; it considers a spatial scale that allows us to observe annual changes, which in turn may be related to environmental variations such as the pycnocline depth and discharge rainwater. Additionally, geostatistical analysis techniques could also be included (e.g., Roa-Ureta and Niklitschek 2007) to enable characterization of the spatial distribution pattern of this species.
Contraction of the M. chilensis beds in the Reloncaví fjord may be associated with i) environmental instability (and the consequent natural deficiencies in recruitment), ii) the removal of recruits as a result of an indeterminate number of artificial substrata (seed collectors) installed and removed annually from the system (Leiva et al. 2007), iii) the exploitation of natural beds (Sernapesca 2013), and iv) predation, among other factors.

These elements, together with the prevailing environmental conditions in the fjord, may be creating scenarios 
that lead to increased variability in the reproductive success of M. chilensis; given the ecological, social, and economic importance of this species along the Chilean coast, the establishment of a monitoring program that considers these factors is imperative.

\section{Conclusion}

Ours results suggest that salinity gradient plays an important role in structuring the community associated with $M$. chilensis, where this species is confined to a narrow habitat that is bordered by physical-chemical restrictions towards the upper boundary. It is also influencing the size distribution of M. chilensis, which showed significant differences between the intertidal and subtidal zones and along the fjord, suggesting a local pattern of size distribution with a low number of recruits at the head of the fjord.

The scarcity of clean mussels and lower densities of covered mussels observed in our study, compared to the observations of previous works suggest a narrowing of the space occupied by the mussel belt and a decrease in the abundance of $\mathrm{M}$. chilensis in the Reloncaví fjord. One approach to studying changes in the abundance of mussel belts could be the contraction/expansion dynamics of subpopulations in the cross-shore spatial distribution of mussels and their relationship with changes in water column salinity, rain, and rain runoff. Contraction of the M. chilensis beds in the Reloncaví fjord may be associated with i) environmental instability, ii) the removal of recruits as a result of an indeterminate number of artificial substrata (seed collectors) installed and removed annually from the system, iii) the exploitation of natural beds and iv) predation, among other factors. These elements may be creating scenarios that lead to increased variability in the reproductive success of $M$. chilensis and therefore threaten the seeds supply from natural environments for mussel aquaculture.

\section{Additional files}

Additional file 1: Table S1. Taxa found along 13 sampling stations between 0 and $15 \mathrm{~m}$ (from the upper tidal level) in the Reloncaví fjord.

Additional file 2: Catastro de bancos naturales de mitilidos en el estuario reloncaví.

\section{Competing interests}

The authors declare that they have no competing interests.

\section{Authors' contributions}

CM carried out in the sample design, participated in sampling, data analysis and drafted the manuscript. MD participated in sampling and data analysis. CA participated in sampling, data analysis. LC participated in sampling drafted the manuscript. SM participated in drafted the manuscript. MA participated in drafted the manuscript. EN participated in drafted the manuscript and data analysis. All authors read and approved the final manuscript.

\section{Acknowledgements}

This study was financed by FONDECYT Project No. 1130716. The collaboration of César Arre Krause, Captain of the L/M Jürgen Winter, César Arre Reyes, and Camilo Almonacid is much appreciated. The authors also thank Susan Angus for the translation of the manuscript and two anonymous reviewers who contributed to improving this article.

\section{Author details}

${ }^{1}$ Fisheries Research Program, Instituto de Acuicultura, Universidad Austral de Chile, Los Pinos s/n, Balneario Pelluco, casilla 1327, Puerto Montt, Chile. ${ }^{2}$ Instituto de Acuicultura, Universidad Austral de Chile, Los Pinos s/n, Balneario Pelluco, 5480000 Puerto Montt, Chile. ${ }^{3}$ Centro Imar, Camino Chinquihue Km 6, Universidad de Los Lagos, 5502764 Puerto Montt, Chile.

Received: 13 October 2014 Accepted: 8 April 2015

Published online: 01 May 2015

\section{References}

Akaike H (1974) A new look at the statistical model identification. IEEE T Automat Contr 19:716-723

Anderson RO, Neumann RM (1996) Length, weight, and associated structural indices. In: Murphy BR, Willis DJ (eds) Fisheries Techniques. American Fisheries Society, Bethesda, Maryland, pp 447-481

Aquaterra Ingenieros Ltda. (2010) Análisis de metodología y determinación de caudales de reserva turísticos. Ministerio de Obras Públicas, http://documentos. dga.cl/ADM5269v1.pdf

Avendaño M, Cantillánez M, Le Pennec M, Varela C, Garcias C (2011) Distribución temporal de larvas de Mytilus chilensis (Hupé, 1954) (Mollusca: Mytilidae), en el mar interior de Chiloé, sur de Chile. Lat Am J Aquat Res 39:416-426

Barría A, Gebauer P, Molinet C (2012) Variabilidad espacial y temporal del suministro larval de mitílidos en el Seno de Reloncaví, sur de Chile. Rev Biol Mar Oceanogr 47:461-473

Brogger MI, Martinez MI, Penchaszadeh PE (2010) Reproduction of the sea urchin Arbacia dufresnii (Echinoidea: Arbaciidae) from Golfo Nuevo, Argentina. J Mar Biol Assoc UK 90:1405-1409, doi:doi:10.1017/S0025315410000445

Burnham KP, Anderson DR (2004) Multimodel inference: understanding AIC and BIC in model selection. Sociol Method Res 33:261-304, doi:10.1177/ 0049124104268644

Buschbaum C, Dittmann S, Hong J-S, Hwang I-S, Strasser M, Thiel M, Valdivia N, Yoon S-P, Reise K (2009) Mytilid mussels: global habitat engineers in coastal sediments. Helgoland Mar Res 63:47-58, doi:10.1007/s10152-008-0139-2

Buzeta R, Winter JE, Chaparro OR, Toro J, Sanhueza M, Matamala M, Gutierrez A, Navarro JM, Arriagada H (1988) Desarrollo de la Maricultura en Chiloé. Universidad Austral de Chile, Valdivia, Chile

Caddy JF (1989) Recent developments in research and management for wild stocks of bivalves and gastropods. In: Caddy JF (ed) Marine Invertebrate Fisheries: Their Assesment and Management. Wiley, New York, pp 665-700

Chaparro OR, Winter JE (1983) The effect of winter period, gametogenesis and spawning on the calorific content of soft parts in Mytilus chilensis. Aquaculture 32:419-422, http://dx.doi.org/10.1016/0044-8486(83)90241-7

Christensen RHB (2012) Ordinal: Regression Models for Ordinal Data, R Development Core Team, http://www.cran.r-project.org/package=ordinal/

Connell JH (1961) The influence of interspecific competition and other factors on the distribution of the barnacle Chthamalus stellatus. Ecology 42:710-723, doi:10.2307/1933500

Daneri G, Pizarro O, Figueroa D, Montero P, Iriarte J, González H, Quiroga E, Ortíz R, Tapia FJ, Geisecke R, Pantoja S, Hall P, Norambuena R (2009) Evaluación de la capacidad de carga del estuario Reloncaví, http://www.fip.cl/resultados Proyectos.aspx?sub=OQ\&an=MjAwNw\&rec=\&tit=

Erlandsson J, McQuaid CD (2004) Spatial structure of recruitment in the mussel Perna perna at local scales: effects of adults, algae and recruit size. Mar Ecol Prog Ser 267:173-185, doi:10.3354/meps267173

Gallager SM, Yamazaki H, Davis CS (2004) Contribution of fine-scale vertical structure and swimming behavior to formation of plankton layers on Georges Bank. Mar Ecol Prog Ser 267:27-43

Hanski I, Gilpin M (1991) Metapopulation dynamics: brief history and conceptual domain. Biol J Linn Soc 42:3-16

Häuseermann V, Försterra G (2009) Fauna Marina Bentónica de la Patagonia Chilena: Guía de identificación ilustrada. Nature in Focus, Santiago

Hunt HL, Scheibling RE (2001) Patch dynamics of mussels on rocky shores: integrating process to understand pattern. Ecology 82:3213-3231 
Leiva G, Santibañez C, Bartheld JL (2007) Definición de criterios biológicos, ambientales, sanitarios y operativos para la instalación de colectores de moluscos bivalvos en la X región. Litoral Austral, http://www.fip.cl/ resultadosProyectos.aspx?sub=Nw\&an $=$ MjAwNQ\&rec $=\&$ tit $=$

Lizama O (2003) Catastro de bancos naturales de mitilidos en el estuario Reloncaví, Cochamó

Lorenzen S, Gallardo C, Jara C, Clasing E, Pequeño G, C.A. M (1979) Mariscos y peces de importancia comercial en el sur de Chile Universidad Austral de Chile, Valdivia

Lougee LA, Bollens SM, Avent SR (2002) The effects of haloclines on the vertical distribution and migration of zooplankton. J Exp Mar Biol Ecol 278:111-134

Marambio J, Maturana S, Campos B (2012) Modelo dinámico de crecimiento de la biomasa para Mytilus chilensis en sistemas de cultivo en líneas. Rev Biol Mar Oceanogr 47:51-64

McCullagh P (1980) Regression models for ordinal data. J R Stat Soc B 42:109-142

McQuaid CD, Lindsay TL (2000) Effect of wave exposure on growth and mortality rates of the mussel Perna perna: bottom up regulation of intertidal populations. Mar Ecol Prog Ser 206:147-154, doi:10.3354/meps206147

Molinet C, Niklitschek E, Coper S, Diaz M, Diaz P, Fuentealba M, Marticorena F (2014) Challenges for coastal zoning and sustainable development in the Northern Patagonian Fjords, Aysén, Chile. Lat Am J Aquat Res 42:18-29

Orensanz JM, Jamieson GS (1998) The assesment and management of spatially structured stocks: an overview of the North Pacific Symposium on Invertebrate Stocks Assessment and Management. In: Jamieson GS, Campbell A (eds) Proceedings of the North Pacific Symposium on Invertebrate Stocks Assessment and Management. Canadian Special Publication Fisheries and Aquatic Sciences, Nanaimo, British Columbia, Canada., pp 441-459

Orensanz JM, Parma A, Iribarne O (1991) Populations dynamics and management of natural stocks. In: Shumway S (ed) Scallops: Biology, ecology and Aquaculture. Elsevier, Amsterdam, pp 765-867

Orensanz JM, Parma A, Turk T, Valero J (2006) Dynamics, assessment and management of exploited natural populations. In: Parsons GJ (ed) Shumway S. Scallops, Biology, Ecology and Aquaculture Elsevier, pp 765-868

Paine RT (1974) Intertidal community structure: Experimental studies on the relationship between a dominant competitor and its principal predator. Oecología 15:93-120

Petes LE, Menge BA, Harris AL (2008) Intertidal mussels exhibit energetic trade-offs between reporduction and stress resistance. Ecol Monogr 78:387-402, doi:10.1890/07-0605.1

Pickard GL (1971) Some physical oceanographic features of inlets of Chile. Fish Res Board Can 28:1077-1106

Pinheiro J, Bates D, DebRoy S, Sarkar D, the R Development Core Team (2013) nlme: linear and nonlinear mixed effects models. R package version 3.1-111. In: 3.1-111. Rpv (ed)

Pulliam HR (1988) Sources, sinks, and population regulation. Am Nat 132:652-661

Reusch T, Chapman A (1997) Persistence and space accupancy by subtidal blue mussel patches. Ecol Monogr 67:65-87

Roa-Ureta R, Arkhipkin Al (2007) Short-term stock assessment of Loligo gahi at the Falkland Islands: sequential use of stochastic biomass projection and stock depletion models. ICES J Mar Sci 64:3-17, doi:10.1093/icesjms/fsl017

Roughgarden J, Iwasa Y, Baxter C (1985) Demographic theory for an open marine population with space-limited recruitment. Ecology 66:54-67

Sernapesca (2013) Anuario estadístico de Pesca, Chile. Sernapesca, http:// www.sernapesca.cl/index.php?option=com_remository\&ltemid $=246 \&$ func $=$ select\&id=892

Silva N, Sievers HA, Prado R (1995) Características oceanográficas y una proposición de circulación para algunos canales Australes de Chile entre $41^{\circ}$ $20^{\prime}$ S y 4640'S. Rev Biol Mar Univ Católica Valpo 30:207-254

The R, Team DC (2013) R: A language and environment for statistical computing ISBN 3-900051-07-0. R Foundation for Statistical Computing, Vienna, Austria

Valle-Levinson A, Sarkar N, Sanay R, Soto D, Leon J (2007) Spatial structure of hydrography and flow in a Chilean fjord, Estuario Reloncaví. Estuar Coast 30:113-126

Viviani C (1979) Ecogeografía del Litoral Chileno. Stud Neotrop Fauna E 14:65-123

Young CM (1995) Behavior and locomotion during the dispersal phase of larval life. In: McEdward L (ed) Ecology of marine invertebrate larvae. CRC Press, Boca Raton, pp 249-278

Zagal C, Hermosilla C, Riedemann A (2001) Guía de invertebrados marinos del litoral Valdiviano. Quebecor World Chile S.A, Valdivia

Zaixso HE (2004) Bancos de cholga Aulacomya atra atra (Molina) (Bivalvia: Mytilidae) del golfo San José (Chubut, Argentina): Diversidad y relaciones con facies afines. Rev Biol Mar Oceanogr 39:61-78

\section{Submit your manuscript to a SpringerOpen ${ }^{\odot}$ journal and benefit from:}

- Convenient online submission

- Rigorous peer review

- Immediate publication on acceptance

- Open access: articles freely available online

- High visibility within the field

- Retaining the copyright to your article

Submit your next manuscript at springeropen.com 